\title{
A study of the relationship between Hess tests and leucocyte ascorbic acid in a clinical trial
}

\author{
BY T. P. EDDY \\ Department of Human Nutrition, London School of Hygiene and \\ Tropical Medicine, Keppel Street, London $W C_{\mathrm{I}} E_{7} H T$ \\ (Received 2, August 1971-Accepted 26 November 1971)
}

\begin{abstract}
I. The results of a previously reported controlled trial of vitamin supplementation of elderly hospital patients, in which capillary resistance was measured by the Hess test, were examined and analysed statistically.

2. Capillary resistance was reduced during successive 3 -monthly tests over a period of iz months and the reduction was related to leucocyte ascorbic acid concentration.

3. It is postulated that the rate of recovery from capillary trauma inflicted by the test was dependent upon the function of ascorbic acid in the hydroxylation of proline to hydroxyproline during collagen synthesis.
\end{abstract}

Since Hess (I9I3) first described the appearance of 'numerous little haemorrhages' after the application of a sphygmomanometer cuff at a pressure of $80 \mathrm{~mm} \mathrm{Hg}$ for 3 min to the arms of children suffering from infantile scurvy, many workers have used the test with various modifications and with contradictory results. Most properly controlled studies in which capillary resistance was related to blood and tissue concentrations of ascorbic acid have been unable to demonstrate a useful relationship between the test and vitamin status, but there have been notable exceptions. Göthlin (I93I, I933) was able to relate the results of the test to vitamin deficiency, and the most striking example of contradiction is the appendix by Scarborough to the report by Bartley, Krebs \& O'Brien (I953) of the Sheffield study of experimental scurvy. Scarborough's Hess tests showed abnormal results in all but one of ten scorbutic young subjects, but the main report of the same investigation found no such relationship. The subject has been reviewed by Munro, Lazarus \& Bell (1947-8) and recently Krasner \& Dymock (1970), using the Hess test and a negative pressure angiosterrometer, came to the conclusion that capillary resistance is independent of buffy layer ascorbic acid.

\section{The clinical studies}

By the courtesy of Dr G. F. Taylor, I have been able to examine his original records of a controlled study which has been previously reported (Griffiths, Brocklehurst, Scott, Marks \& Blackley, 1967; Brocklehurst, Griffiths, Taylor, Marks, Scott \& Blackley, I968; Griffiths, 1968; Taylor, 1968). In this study of eighty elderly hospital patients selected at random, forty were given a daily multivitamin tablet containing $200 \mathrm{mg}$ ascorbic acid for a year and forty controls were given a placebo. Measurements of leucocyte ascorbic acid were made at 3-monthly intervals. Hess tests were performed at the same time by applying a sphygmomanometer cuff to the right arm at a pressure of $100 \mathrm{~mm} \mathrm{Hg}$ for 5 min and counting petechiae appearing in a circle of skin of $25 \mathrm{~mm}$. 
Table I. Mean values with their standard errors for leucocyte ascorbic acid concentrations $\left(\mu \mathrm{g} / 1 \mathrm{O}^{8} \mathrm{WBC}\right)$ and counts of capillary haemorrhages in Hess tests in elderly patients

Examination

Pilot study

I (o months)

2 (3 months)

3 (6 months)

4 (9 months)

5 (12 months)

After trial (I8 months)

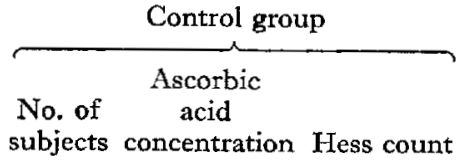

$\overbrace{\text { No. of } \begin{array}{c}\text { Ascorbic } \\ \text { acid }\end{array}}^{\text {Treated group }}$$$
3 x
$$$$
40
$$$$
35
$$$$
33
$$$$
22
$$$$
27
$$

$\begin{array}{lr}- & 6 \cdot 1 \pm I \cdot I \\ I 5 \cdot 2 \pm I \cdot 2 & 12 \cdot 3 \pm I \cdot 2 \\ 19 \cdot 9 \pm I \cdot 7 & 12 \cdot 8 \pm I \cdot 5 \\ 27 \cdot 9 \pm 2 \cdot 3 & 21 \cdot 8 \pm 2 \cdot 0 \\ 24 \cdot 6 \pm 2 \cdot 6 & 28 \cdot 5 \pm 2 \cdot 8 \\ 26 \cdot 6 \pm 3 \cdot I & 32 \cdot 3 \pm 2 \cdot 1 \\ - & 24 \cdot 3 \pm 2 \cdot 8\end{array}$

There were eleven deaths in the control group and seven deaths in the treated group between the first and fifth examinations.

Table 2. Numbers of surviving elderly patients at given concentrations of leucocyte ascorbic acid and Hess counts of capillary haemorrhages at the fifth examination

$\begin{array}{ccccc}\begin{array}{c}\text { Leucocyte } \\ \text { ascorbic acid } \\ \left(\mu \mathrm{g} / 10^{8} \text { WBC }\right)\end{array} & \begin{array}{c}\text { Haemorrhage counts in Hess test } \\ 0-9\end{array} & \text { 10-29 } & 30+ & \begin{array}{c}\text { Total } \\ \text { patients }\end{array} \\ 0-19 & 1 & 4 & \text { ro } & 15 \\ 20-39 & 9 & 4 & 7 & 20 \\ 40+ & 12 & 8 & 3 & 23 \\ \text { Total patients } & 22 & 16 & 20 & 58 \\ & \chi_{4}^{2}=x_{3.78} ; P<0.01 . & \end{array}$

Each patient had received at least five Hess tests at 3-monthly intervals. Some had received sixorseven.

diameter over the insertion of the biceps. Some subjects received a preliminary Hess test 3 months before the start of the trial, and forty-eight survivors were tested 6 months after the conclusion. The test was blind. On present inspection, the manuscript records of the clinical observer are clearly those written at the time of clinical examination without subsequent revision or alteration.

Although Brocklehurst et al. (I968) obtained highly significant statistical differences for values of Hess tests at the end of their trial between treated and control groups, Griffiths (1968) was unable to show an association between the Hess test and ascorbic acid deficiency designated as less than $24 / \mu \mathrm{g}$ per $10^{8}$ white blood cells (WBC). But examination of the clinical records reveals a clear association between the 3 monthly values for leucocyte ascorbic acid concentrations measured by Griffiths and the Hess tests measured at the same time independently by Taylor. The results show interesting features which tend to mask this association.

\section{RESULTS}

Statistical analyses of the results are shown in Tables $I$ and 2 and in Fig. $I$.

At the five successive examinations during the trial the coefficients of linear correlation between leucocyte ascorbic acid concentrations and Hess counts were: 


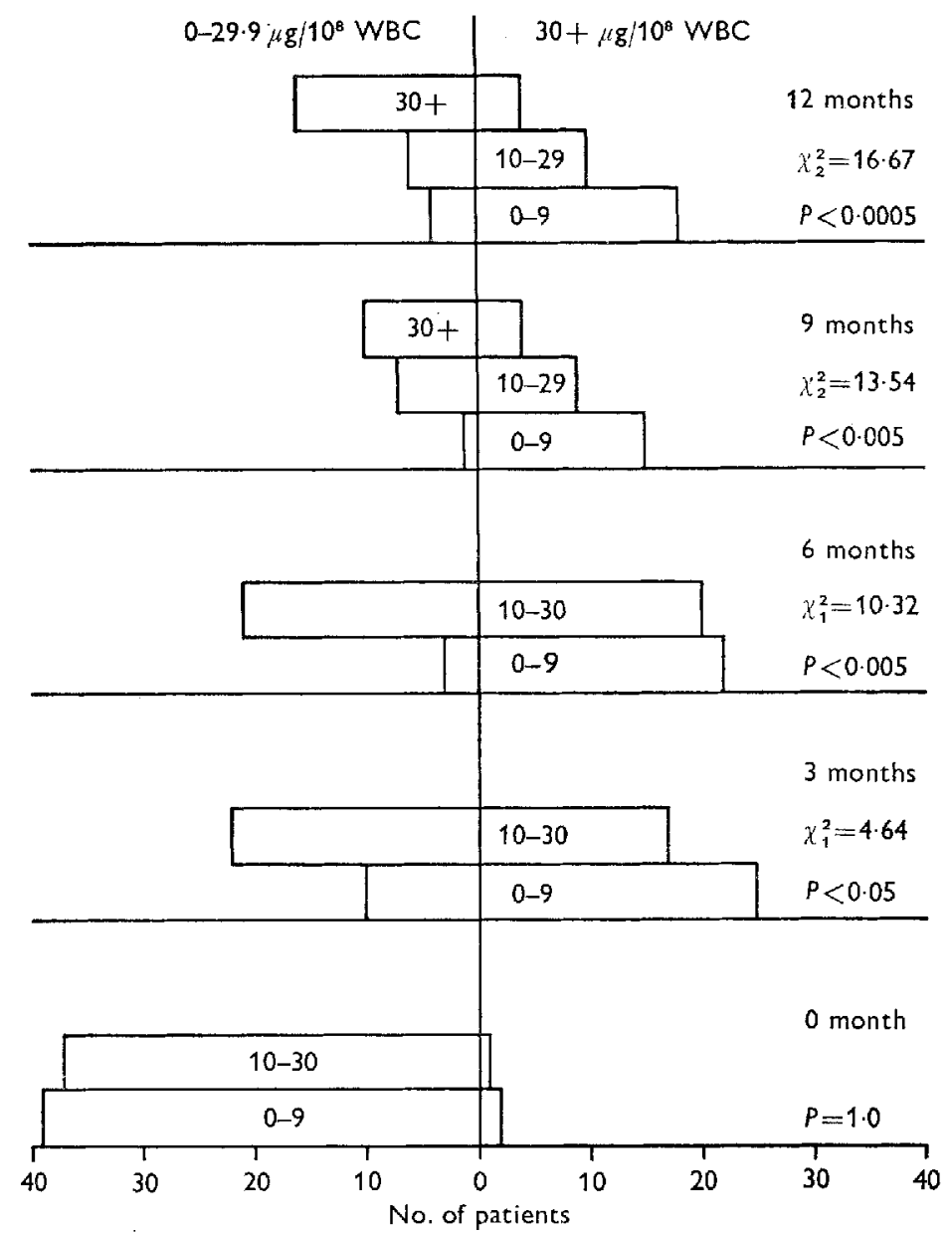

Fig. I. Relationship in elderly patients between leucocyte ascorbic acid concentration and number of capillary haemorrhages in Hess tests at intervals of 3 months. The numbers of haemorrhages are shown in the columns of the histograms. In the three columns showing a total of I 8 tests with ten to thirty haemorrhages, ten tests with more than thirty haemorrhages are included: two at 0 month; two at 3 months; six at 6 months.

$r_{1}=0, r_{2}=-0.02, r_{3}=-0.44, r_{4}=-0.5^{2}, r_{5}=-0.44$. The last three coefficients $\left(r_{3}, r_{4}, r_{5}\right)$ are statistically highly significant $(P<0.00 \mathrm{I})$.

Twenty-six of the controls who were still in hospital were Hess-tested 6 months after the conclusion of the trial. The coefficient of correlation between the last recorded leucocyte concentration and the final Hess count taken 6 months later was $r=-0.54(P<0.01)$.

In both treated and control groups, Table $I$ shows that there was a highly significant rise in Hess counts between the preliminary examination 3 months before the start of the trial and the first examination of the trial, to about double the original values. This may be partly attributed to increased attention by the observer to tests made in the trial as compared to tests in the pilot study, and it may be partly due to a real increase occurring at successive examinations in vitamin-deficient subjects, an increase which 
was constantly shown by the control group. Each examination of the control group up to the conclusion of the trial resulted in a higher mean Hess count than that found in previous examinations; there are highly significant differences between counts at the beginning, middle and end of the trial. In the treated group there is no statistically significant difference between the results of successive examinations in the trial, and there is none between those of the five trial examinations and the final examination 6 months after the trial. The changes which occurred in the control group, therefore, appear to be due to some instability in the subjects rather than to observer error.

Fig. I shows an increasing relationship between Hess counts and leucocyte concentrations, becoming apparent at the $2 n d$ test at the 3 rd month when a clear distinction emerged between numbers of haemorrhages counted in patients with concentrations less than $3 \circ \mu \mathrm{g} / \mathrm{I}^{8} \mathrm{WBC}$ and in those with $3 \circ \mu \mathrm{g} / \mathrm{ro}^{8} \mathrm{WBC}$ or more. By the fifth examination at the conclusion of the I2 months' trial, Table 2 shows statistically highly significant differences between subjects grouped in ranges of $20 \mu \mathrm{g} / \mathrm{I}^{8} \mathrm{WBC}$.

\section{DISCUSSION}

One possible reason for these progressive differences in the Hess test as the trial proceeded is that each application of the pressure cuff for $5 \mathrm{~min}$ inflicted some degree of trauma on capillaries, even where no haemorrhages were visible on clinical examination. Subjects who were treated with ascorbic acid, or who had high tissue concentrations, made a complete recovery from any capillary trauma within 3 months, but deficient subjects did not recover and therefore showed an increasing liability to capillary haemorrhage at successive examinations. There is some supporting evidence for this in the observation by Brocklehurst et al. (1968) that spontaneously occurring skin haemorrhages counted on the arms before the Hess test increased at successive examinations of the control group. These increases appear to have been predominantly in the right arm, the arm used for Hess tests in previous examinations.

Göthlin (I933) considered that in a series of tests on one person it was necessary to allow at least a fortnight, but preferably a month, to intervene between each test so that the ruptured vessels have time to heal perfectly. Udenfriend ( $\mathrm{x} 966$ ) has shown that in collagen synthesis, hydroxylation occurs after the incorporation of the proline residue into the peptide chain, and that the hydroxylation of the peptidyl proline is dependent upon ascorbic acid. Priest (1970) demonstrated that the formation of the hydroxyproline-containing protein of basement membrane in cell culture (as measured by the incorporation of radioactivity from tritium-labelled proline into peptidyl proline and hydroxyproline) was stimulated by ascorbic acid and restricted by deficiency. As the synthesis of epithelial and vascular basement membrane appears, therefore, to be dependent on ascorbic acid, Priest has suggested that the haemorrhagic 'scorbutic spots' of adult scurvy may be attributed to a restriction of synthesis of basement membrane. Limitations imposed by low concentrations of tissue ascorbic acid on the repair of basement membrane damaged to the point of rupture by successive tension stresses would account for the instability of controls shown in Table $\mathbf{r}$. The significant correlation $(r=-0.54 ; P<0.01)$ between the last ascorbic acid estimates for the 
controls and the final Hess test 6 months later suggests that recovery of damaged basement membrane was limited by the tissue concentration of ascorbic acid over a period of 6 months; apparently at the lowest concentrations the synthesis of basement membrane was still restricted.

In an investigation of fourteen elderly patients, Windsor \& Williams (1970) demonstrated an increased excretion of hydroxyproline after treatment with $\mathrm{Ig}$ ascorbic acid daily of patients with ascorbic acid concentrations below $15 \mu \mathrm{g} / \mathrm{IO}^{8} \mathrm{WBC}$, suggesting that hydroxylation of proline and the synthesis of collagen and basement membrane were restricted at this concentration. At the start of the trial of Brocklehurst et al. (I968), sixty patients had concentrations below $20 \mu \mathrm{g} / 10^{8} \mathrm{WBC}$, of which twenty-three were below $10 \mu \mathrm{g} / 10^{8} \mathrm{WBC}$. At the end of the trial fifteen were below $20 \mu \mathrm{g} / \mathrm{ro}^{8} \mathrm{WBC}$. In their recent experiments Baker, Hodges, Hood, Sauberlich, March \& Canham (197I) and Hodges, Hood, Canham, Sauberlich \& Baker (197I) found that a concentration of $0.3 \mathrm{mg}$ ascorbic acid/100 $\mathrm{ml}$ in whole blood was critical and at this point blood levels failed to correlate with the size of the body pool of ascorbic acid. Their scorbutic subjects had concentrations higher than this on many occasions during overt manifestations of scurvy. This concentration corresponds to approximately $\mathrm{I} 5 \mu \mathrm{g} / \mathrm{ro}^{8} \mathrm{WBC}$ in the estimates given by Griffiths ( $\mathrm{I} 968$ ).

The instability of deficient subjects may go some way to explain discrepancies in results from this test. Over the whole range of the controlled trial there was no relationship between vitamin status and capillary resistance, each stage of the trial has to be considered separately to observe an association. Studies based on single tests of each subject would show no correlation with vitamin status; in Table I the lowest tissue concentrations of vitamin are associated with the highest capillary resistance. The results from this controlled trial do not therefore conflict with those of Krasner \& Dymock ( 1970 ), which appear to be based on single Hess tests. Krasner \& Dymock note that the Hess test is difficult to repeat because of the extent of petechial formation over the whole arm.

Tests for capillary resistance are not specific tests for ascorbic acid deficiency. Elderly patients commonly suffer from disturbances of adrenocortical activity and disorders of collagen metabolism other than ascorbic acid deficiency. But deficiency of ascorbic acid is one of the collagen diseases, and if it occurs it appears likely that there would be some interrelationship between the deficiency and related disorders with which it shares a similar pathology and symptomatology. Tests for capillary resistance appear to have a very limited value in the diagnosis of specific vitamin deficiency.

\section{REFERENCES}

Baker, E. M., Hodges, R. E., Hood, J., Sauberlich, H. E., March, S. C. \& Canham, J. E. (I97I). Am. F. clim. Nutr. 24, 444 .

Bartley, W., Krebs, H. A. \& O’Brien, J. R. P. (r953). Spec. Rep. Ser. med. Res. Coun. no. 280.

Brocklehurst, J. C., Griffiths, L. L., Taylor, G. F., Marks, J., Scott, D. L. \& Blackley, J. (r968). Geront. din. 10, 309.

Göthlin, G. F. (1931). Skand. Arch. Physiol. 61, 22.5.

Göthlin, G. F. (1933). F. Lab. clin. Med. 18, 484 .

Griffiths, L. L. (1968). In Vitamins in the Elderly p. 34 [A. N. Exton-Smith and D. L. Scott, editors]. Bristol: John Wright. 
Griffiths, L. L., Brocklehurst, J. C., Scott, D. L., Marks, J. \& Blackley, J. (1967). Geront. clin. 9, I. Hess, A. F. (19r3). Proc. Soc. exp. Biol. Med. II, 130.

Hodges, R. E., Hood, J., Canham, J. E., Sauberlich, H. E. \& Baker, E. M. (1971). Am. F. clin. Nutr. 24, 432 .

Krasner, N. \& Dymock, I. W. (1970), Int. F. Vitam. Res, 40, 427.

Munro, H. N., Lazarus, S. \& Bell, G. H. (1947-8). Nutr. Abstr. Rev. 17, 291.

Priest, R. E. (I970). Nature, Lond. 225, 744 .

Taylor, G. F. (1968). In Vitamins in the Elderly p. 5 I [A. N. Exton-Smith and D. L. Scott, editors]. Bristol: John Wright.

Udenfriend, S. (I966). Science, N.Y. 152, 1335.

Windsor, A. C. W. \& Williams, C. B. (1970). Br. med. F. i, 732. 